\title{
Analysis and Application of Flood Estimation Methods during Project Construction
}

\author{
YIN Jishu ${ }^{\mathrm{a}} \quad$ Wang Jianbin \\ School of Civil Engineering, \\ University of South China, \\ Hengyang, Hunan Province, China \\ ayjs6508@163.com
}

Keywords: Construction, Flood Estimation, Analysis of the Application.

Abstract. An estimation of the design flood is required for projects constructed across rivers. Flood peak values exert direct effects on the selection of construction proposals, the cost prediction, and the construction safety. Differenct methods for flood estimation may be determined specifically in each case. Proper selection of flood estimation methods is of great significance for ensuring a smooth construction process.

To ensure the construction progress and quality of the project, design flood values should be determined for each specific construction stage, serving as the basis of the overall construction arrangement. When small- or medium-sized projects are constructed across a river, a cofferdam is commonly built first to drain off water from the riverbed, creating a dry work environment for the major work to proceed. The design of cofferdams must rely on the design flood estimation during different constrution periods. Bulding cofferdams in a right way can accelerate the construction pace and reduce the construction cost, while disruption of the construction process could result in serious threat or further damage. Therefore, the determination of flood peak flow prior to construction is of critical importance.

\section{Criteria of design flood estimation}

The criteria of design flood can be considered as flood prevention standards for safety purpose, also known as criteria for design of diversion works. In the present, design flood computation are based on mathematical and statistical principles. Generally, in the light of the specific conditions such as hydrological charateristics, divension methods, construction duration, project scale and its importance, flood with a given frequency is chosen as the design standard. Temporary structures related to the major flood control project include cofferdams, diversion channels and tunnels. The criteria of design flood estimation are presented in Table 1.

Table 1. Return period of temporary structures

\begin{tabular}{|c|c|c|c|c|}
\hline \multirow{2}{*}{ Structure type } & \multicolumn{4}{|c|}{ Temporary structure level } \\
\cline { 2 - 5 } & 2 & 3 & 4 & 5 \\
\cline { 2 - 5 } & \multicolumn{4}{|c|}{ Return period } \\
\hline Soil and stone structure & $>50$ & $50 \sim 30$ & $30 \sim 20$ & $20 \sim 10$ \\
\hline Concrete structure & $>20$ & $20 \sim 10$ & $10 \sim 5$ & $5 \sim 3$ \\
\hline
\end{tabular}

Methods for design flood estimatimation include empirical analysis, frequency analysis, and hydrograph method. Small- and medium- sized projects are mostly in accordance with criteria and observed data but careful consideration should be given. If the cofferdam wreck would bring serious consequences, design standards should be improved. And vice versa, design standards can be properly reduced. Meanwhile, construction diversion standards can not be regard as immutable. They ought to be constantly adjusted with the progress and requirement of project. Therefore, for 
the purpose of downsizing construction measures, the progress seeks to be accelerated, so that a safe elevation can be built before the flood arrives.During construction, if the flood exceeded above standards, necessary emergency measures should be taken properly to ensure the safety of construction.

\section{Methods for design flood computation}

Design flood computation requires collection of adequate meteorological and hydrological information from the local area and its adjacent regions, and analysis of flood seasonal variation. In regions with insufficient hydrological data, it is necessary to apply appropriate interpolation and extrapolation. Adjustments and investigations are also required. In addtion, regionalisation methods or other flood estimation methods for small catchments can be performed to deal with the missing data.

Design flood computation includes design flood peak, flood peak discharge and design flood hydrograph. For small- and medium-sized brigdes and culverts, design flood is usually derived from streamflow data and rainfall data.

\section{Design flood computation using streamflow data}

The method based on streamflow records is basically the frequency analysis of observed data. For intermediate project construction that cannot be completed within one dry season and that takes over a period of one year, it is required for the cofferdam to withstand flood during the flood season. Therefore, the design flood estimation for cofferdams should be performed on the annual maximum discharge.

For projects with long construction duration, design flood can be estimated seasonally. The duration of each season depends on catchment hydrological characteristics and construction requirements. Drought season, normal season, and flood season are generally adopted. Several alternative construction periods and their respective starting and ending points are supposed to be proposed by construction companies and further frequency analysis in terms of flood peak is performed for each period. By a comparison of the frequency analysis results, an appropriate construction period with long duration and relatively low flood discharge can be derived. This method is currently adopted at circumstances as long series of flood data and representative series are available. However, in situations where only short data series are available, this method is not suitable and sometimes even poses a risk to the structure. In this case, hydrological charateristics have to be considered carefully for the selection of construction period. A typical example is presented as follows.

It is hypothesized that the observed flood data are available at the site of interest. In accordance to the building type, construction progress, construction duration, and hydrological features, the construction company proposed four construction periods as below: $1^{\text {st }}$ August $-15^{\text {th }}$ May, $1^{\text {st }}$ August $-15^{\text {th }}$ April, $1^{\text {st }}$ September $-15^{\text {th }}$ April, and $1^{\text {st }}$ October $-28^{\text {th }}$ February. Annual maximum flood discharge was given in the Table 2 to calculate the frequency and the results were used to select the construction period.

Table 2.

\begin{tabular}{|c|c|c|c|c|}
\hline Construction Period & $\bar{Q}\left(\mathrm{~m}^{3} / \mathrm{s}\right)$ & $C_{\mathrm{v}}$ & $1 \%$ & $5 \%$ \\
\hline $1^{\text {st }}$ August $-15^{\text {th }}$ May & 4200 & 0.43 & 9500 & 7540 \\
\hline $1^{\text {st }}$ August $-15^{\text {th }}$ April & 3210 & 0.31 & 5950 & 5000 \\
\hline $1^{\text {st }}$ September $-15^{\text {th }}$ April & 3060 & 0.27 & 5300 & 4540 \\
\hline $1^{\text {st }}$ October $-28^{\text {th }}$ February & 1710 & 0.66 & 5310 & 3860 \\
\hline
\end{tabular}

The calculation results in the Table 2, combined with construction conditions, show that the period of 1 st September -15 th April is relatively reasonable for construction. However, in long series a flood reaching $8720 \mathrm{~m}^{3} / \mathrm{s}$ occurred on 12th April of one year. It is slightly larger than the 
largest flood of May over the years in the whole series, $8500 \mathrm{~m}^{3} / \mathrm{s}$. And this situation is almost impossible to happen in the theoretical frequency curve of selected period, which apparently disaccords with the facts. So if considering one month ahead and later, that is from 1st August to 15 th May, the $8720 \mathrm{~m}^{3} / \mathrm{s}$ 's rate of flow is equivalent to $3.5 \%$ of the frequency, which is more reasonable. Hence, after analysis and comparison, the consequence of 1st August - 15th May should be chosen as the construction design flood.

\section{Design flood computation using rainfall data}

Observed streamflow data are often inadequate or absent in some samll- and medium-sized catchments, in which long series of rainfall data that are satisfactory for frequency analysis can be alternatively used at the site of interest. Given that long series of rainfall data are Interpolation and extrapolation of the observed data followed by the analysis of the long series of rainfall data in each section of the construction period may be performed when series data are not adequate in either length or quality.

Mean daily rainfall intensity $\overline{P_{24}}$, variation coefficient $C_{V 24}$, and rainstorm attenuation index $\mathrm{n}$ can be obstained by the statistical analysis with construction periods as statistical objectives. Using these parameters, design rainstorm and further design flood can be obtained by rational formula.

Rational formula is the commly used method of estimating design flood in small- and mediumsized catchments where the data are often missing or unsatisfactory for analysis. Due to the limited flood detention storage capacity of small rivers and the weak capibility of modulation and conservation, design flood for small- and medium-sized hydraulic structures could be the design flood peak discharge and total flood volume and flood hydrograph are a secondary consideration. In China, this method has been introduced into the manual of hydrological computation, in which reference data are provided on the attached chart for simplified calculation.

Since the distance between effective rainfall that is distributed in different positions of a catchment and the watershed outlet is different, the time needed for runoff to reach the watershed outlet $\tau$ varies. When the duration of the effective rainfall $t_{b}$ is larger than or equal to $\tau$, the flood peak discharge $Q_{m}$ at the watershed outlet is calculated by the maximum intensity of effective rainfall in the period of $\tau$ :

$$
Q_{m}=0.278 \frac{R_{\tau}}{\tau} F=0.278 \alpha \bar{a}_{\tau} F
$$

When $\mathrm{t}_{\mathrm{b}}$ is smaller than $\tau, Q_{m}$ at the watershed outlet is calculated by the total intensity of effective rainfall in part of the catchment:

$$
Q_{m}=0.278 \frac{R_{\mathrm{t}_{\mathrm{b}}}}{t_{b}} F=0.278 \alpha \bar{a}_{t_{b}} F_{0} .
$$

where: $Q_{\mathrm{m}}$ - peak discharge $(\mathrm{m} 3 / \mathrm{s})$

$R_{\mathrm{t}}$ - maximum intensity of effective rainfall in the period of $\tau(\mathrm{mm})$

$R_{\mathrm{t}_{\mathrm{b}}}$ - maximum intensity of effective rainfall in the period of $\mathrm{t}_{\mathrm{b}}(\mathrm{mm})$

$\mathrm{F}, \mathrm{Fo}$ - the entire catchment area, the sub-catchment area $\left(\mathrm{km}^{2}\right)$

$\tau-$ the time needed for water to reach the watershed outlet (h)

$\alpha$ - runoff coefficient

$a_{\mathrm{t}}$ - the average intensity of rainfall for the time of concentration $(\mathrm{mm} / \mathrm{h})$

For example, it is hypothesized that the design flood is required for a site of interest where the catchment area F is $50 \mathrm{~km}^{2}$ and the temporary structure is at level five. Design peak discharge, total design flood volume and design hydrograph are being calculated below. 
Sine there are no streamflow data available at the site of interest, the design flood can be derived from rainfall data. The return period is considered as 10 years for the temporary structure of level five according to the criteria. $\overline{a_{\tau}}=20.2 \mathrm{~mm} / \mathrm{h}, \alpha=0.5, \tau=2.27 \mathrm{~h}$, which are derived from series rainfall data.

Design peak discharge is calculated by Eq. 1:

$$
Q_{m}=0.278 \alpha \overline{a_{\tau}} F=0.278 \times 0.5 \times 20.2 \times 50=140\left(\mathrm{~m}^{2} / \mathrm{s}\right)
$$

Total design flood volume is calculated as:

$$
\begin{aligned}
& P_{\tau}=\overline{a_{\tau}} \alpha \tau=20.2 \times 0.5 \times 2.27=22.9(\mathrm{~mm}) \\
& W_{p}=1000 P_{\tau} F=1000 \times 22.9 \times 50=114.5 \times 10^{4}\left(\mathrm{~m}^{3}\right)
\end{aligned}
$$

For design hydrograph, the total duration is calculated by the equivalent triangular method:

$$
\begin{aligned}
& T=\frac{2 W_{p}}{Q_{m}}=\frac{2 \times 114.5 \times 10^{4}}{140} \approx 4.5 \mathrm{~h} \\
& T=\text { rising duration } t_{1}+\text { falling duration } t_{2} \\
& \text { If } t_{2}=2 t_{1}, \\
& t_{1}=1.5 \mathrm{~h}, t_{2}=3.0 \mathrm{~h}
\end{aligned}
$$

\section{Conclusion}

The design flood estimation is of great importance for construction of hydraulic structures within the river and is closely related to the construction safety and the determination of construction plans and budget. The present study discusses the criteria of design flood estimation, in which a specific estimation method is adopted upon variant data situations. A detailed analysis of two computation methods for estimating design flood is carried out in this study. In summary, this study deepens the understanding of effective design flood estimation and provides insights for new construction strategies.

\section{References}

[1] Chi Xiuwen, Lei Chunying, Yu Le, He Zhiliang, Lin Chi, Gao Peicheng: 武汉二七长江大桥 施工安全风险因素频数权重层次分析 (土木工程与管理学报, 2014). [In Chinese]

[2] 水利水电工程围堰设计规范 (SL645-2013). [In Chinese]

[3] 公路桥涵施工技术规范(JTJ041-2000) [In Chinese]

[4] Guo Fengmin, Li Ruitao, Cheng Sheng: 桥涵水力水文, 北京理工大学出版社(2010). [In Chinese]

[5] Ye Shouze: 水文水利计算, 水利水电出版社(1997). [In Chinese]

[6] Zhu Feng: 公路工程施工, 机械工业出版社(2014). [In Chinese]

[7] 暴雨洪水查算手册(1988) [In Chinese]

[8] Wang Xiushan: 道路与桥梁施工技术, 机械工业出版社(2016). [In Chinese] 